\title{
Aquatic biodiversity across a hydroperiod gradient of lakes, ponds, and wetlands in Torres del Paine National Park, Chile
}

\author{
Biodiversidad acuática a través de un gradiente hidroperiodo de lagos, \\ lagunas y humedales en el Parque Nacional Torres del Paine, Chile
}

Christine M. Glaude ${ }^{1}$, Rick A. Relyea ${ }^{2}$ \& Isaac M. Ortega ${ }^{1}$

\begin{abstract}
Understanding how communities are structured under relatively pristine conditions is critical to understanding their ecology and evolution. In this study, we examined the structure of aquatic communities in the Torres del Paine National Park in Chilean Patagonia. Using dipnet surveys, we quantified the distribution of larval anurans and all macroinvertebrates from 81 habitats across a hydroperiod gradient (lakes, ponds, permanent wetlands, semi-permanent wetlands, and temporary wetlands). Compared to surveys conducted at similar northern latitudes that have high species richness and hydroperiod specialization, Patagonian habitats contained a dramatically lower richness with many taxa widely distributed across the hydroperiod gradient. Overall, taxonomic richness was lowest in temporary wetlands and lakes, but highest in habitats with intermediate hydroperiods. The cause of this unimodal relationship was a small decline in the prevalence of all taxa on the temporary end of the gradient (due to habitat desiccation) but a complete exclusion of several taxa on the most permanent end of the gradient (due to fish predation). These results are consistent with North American studies of aquatic communities and lend support to the hypothesized effect of disturbance on the distribution of biodiversity. The fact that most biodiversity occurs in the temporary and intermediate hydroperiods underscores the importance of managing the full range of aquatic
\end{abstract}

communities rather than only concentrating on the larger and more apparent lakes.

\section{Key words:}

aquatic community, wetlands, hydroperiod gradient, Torres del Paine, Patagonia, Chile.

\section{Resumen}

Un entendimiento de cómo se estructuran las comunidades relativamente prístinas es fundamental para comprender su ecología y evolución. En este estudio, examinamos la estructura de las comunidades acuáticas en el Parque Nacional Torres del Paine en la Patagonia Chilena. Utilizando redes de inmersión, cuantificamos la distribución de anuros de larvas y macro-invertebrados de 81 hábitats a lo largo de un gradiente de hidroperíodo (lagos, lagunas, humedales permanentes, humedales semipermanentes y humedales temporales). En comparación con los estudios realizados

1 Department of Natural Resources and the Environment, University of Connecticut, Storrs, Connecticut, USA 06269 crelyea28@gmail.com;

$\measuredangle$ morty.ortega@uconn.edu)

2 Department of Biological Sciences, Darrin Fresh Water Institute, Rensselaer Polytechnic Institute, Troy, NY 12980 relyer@rpi.edu 
en latitudes septentrionales similares, que tienen una gran riqueza de especies y una especialización en hidroperíodo, los hábitats de la Patagonia contenían una riqueza mucho menor con muchos taxones ampliamente distribuidos a lo largo del gradiente de hidroperíodo. En general, la riqueza taxonómica fue más baja en humedales temporales y lagos, y más alta en hábitats con hidroperíodos intermedios. La causa de esta relación unimodal fue una pequeña disminución en la prevalencia de todos los taxones en el extremo temporal del gradiente (debido a la desecación del hábitat) pero una exclusión completa de varios taxones en el extremo más permanente del gradiente (debido a la depredación de peces). Estos resultados son consistentes con los estudios de Norte América de las comunidades acuáticas y prestan apoyo al efecto hipotético de la perturbación en la distribución de la biodiversidad. El hecho de que la mayor parte de la biodiversidad ocurra en los hidroperíodos temporales e intermedios subraya la importancia de gestionar toda la gama de comunidades acuáticas en lugar de concentrarse únicamente en los lagos más grandes y más vistosos.

\section{Palabras clave:}

comunidades acúaticas, humedales, gradients de hidroperíodos, Torres del Paine, Patagonia, Chile.

\section{INTRODUCTION}

The effective management of any community requires that we document how communities are structured under relatively pristine conditions and understand the factors responsible for this structure. This goal is becoming ever more challenging as we increasingly alter landscapes around the world, either directly via habitat manipulations or indirectly via climatic changes. Most of our understanding of ecological communities and our guidelines for managing them comes from decades of work conducted in some of the most developed regions of the world (e.g., Connell, 1983; Menge, 1995; Wellborn et al. 1996; Werner et al. 2007; McCauley et al. 2008; Hoverman et al. 2011). We know considerably less about communities in undeveloped regions of the world, yet undeveloped regions offer us an excellent opportunity to test ecological theory while simultaneously documenting the species richness and relative abundance that can serve as reference conditions for future management.

The use of "reference conditions" has been repeatedly employed as a strategy for managing aquatic communities (Reynoldson et al. 1997) and includes documenting the composition of aquatic communities under pristine conditions along gradients of physical and biological conditions (Wright, 1995; Marchant et al. 1997; Snodgrass et al. 2000). Once we understand how species composition varies with changes in natural gradients, we can predict future changes in biodiversity as the landscape becomes altered by human intervention (Burroni et al. 2011, Epele \& Miserendino, 2015, 2016) . In this way, we can separate changes in biodiversity due to natural changes in the landscape from humaninduced changes in the landscape (Snodgrass et al. 2000).

Aquatic communities are typically structured by abiotic conditions, predation, and competition (Connell, 1983; Schoener, 1983; Leibold, 1989; Dunson; Travis, 1991; Menge 1995). A variety of abiotic conditions can affect aquatic communities, including variation in temperature, $\mathrm{pH}$, dissolved oxygen, and salinity (Pennak, 1989; Dunson \& Travis, 1991; Wollheim \& Lovvorn, 1996; Wetzel, 2001). However, the most dominant abiotic factor is hydroperiod (Wiggins et al. 1980; Schneider \& Frost, 1996; Wellborn et al. 1996). Short hydroperiods (habitats that dry every year) restrict communities to those taxa that can rapidly develop and metamorphose or produce resting eggs prior to the habitat drying. Intermediate hydroperiods (habitats that dry every few years) are long enough to permit many more taxa to exist and these taxa tend to be well adapted to competition for limited resources. The most permanent hydroperiods (i.e., lakes) typically contain predatory fish which exclude many intermediate-hydroperiod taxa. Thus, hydroperiod gradients, competition, and predation are predicted to cause unimodal relationships between hydroperiod and species 


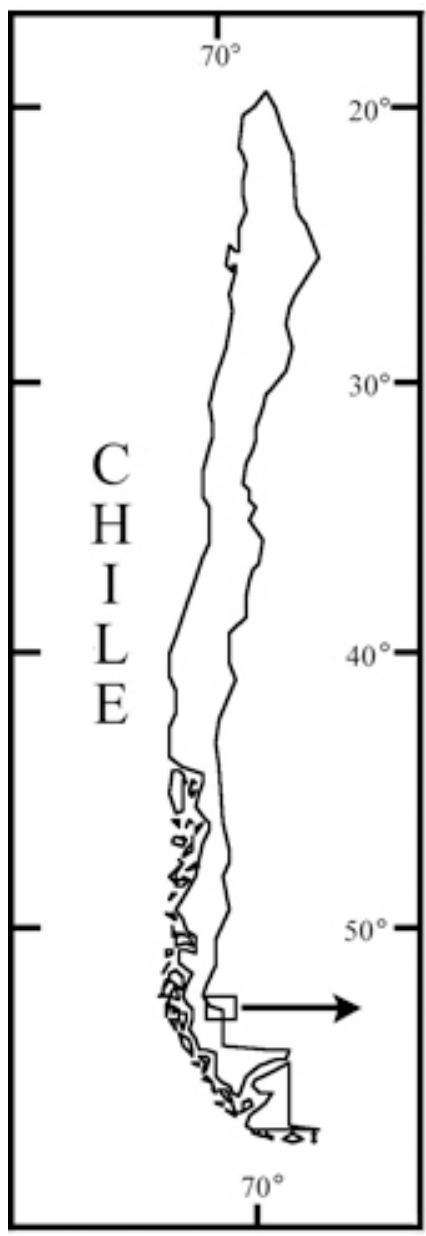

TORRES DEL PAINE

NATIONAL PARK

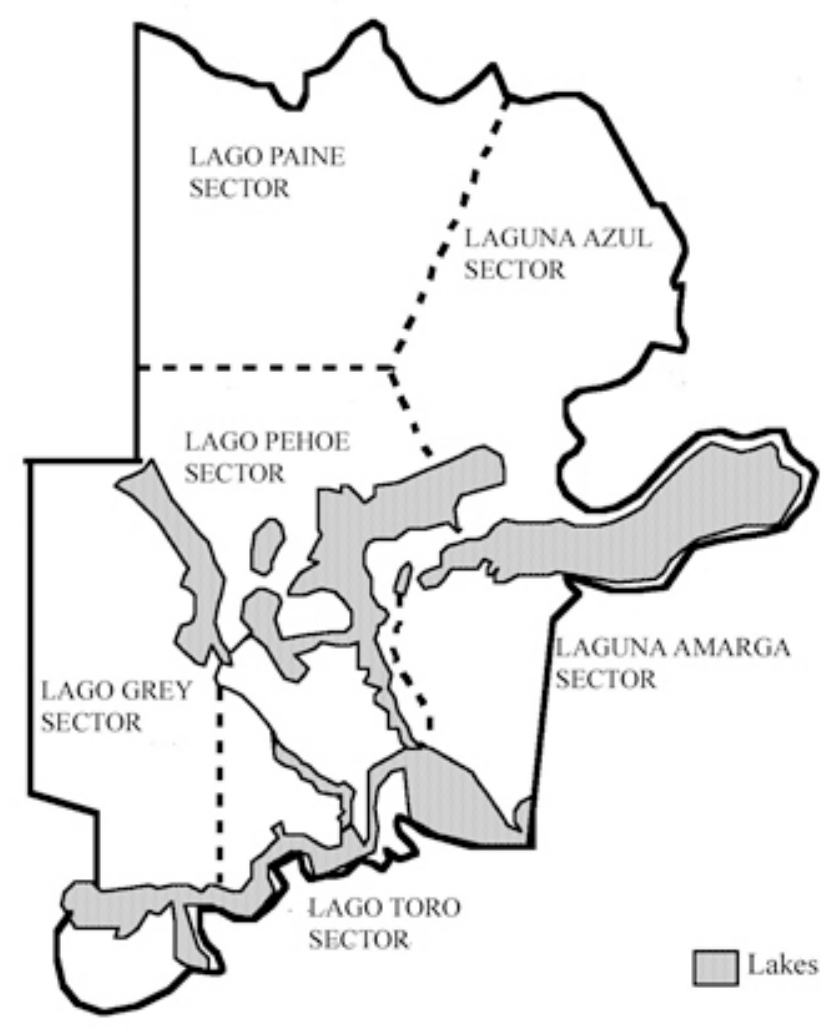

Fig. 1. Study area at Torres del Paine National Park in southern Chile (5055' south and $73^{\circ} 05^{\prime}$ west) showing the Lago Sarmiento, Laguna Amarga, and Lago Grey sectors.

richness (Wiggins et al. 1980; Leibold, 1989; Schneider \& Frost, 1996; Wellborn et al. 1996). The role of these factors in structuring aquatic communities has been well studied in North America and Europe (Wellborn et al. 1996) but there have been few studies from less developed regions of the world. Our objective was to test whether these factors caused unimodal species richness in aquatic habitats in the Chilean Patagonia and to establish the reference conditions of species composition as a basis for future management of Patagonian wetlands, ponds, and lakes. We met this objective by surveying the aquatic fauna over two years in a large number of aquatic habitats throughout the Torres del Paine National Park, Magallanes Region, Chile.
METHODS

\section{Study Area}

The Torres del Paine National Park (51 ${ }^{\circ}$ ' S, $72^{\circ} 55^{\prime} \mathrm{W}$ ) is a 242,000 ha park that was declared a United Nations Reserve of the Biosphere in 1978 (Fig. 1). Previous aquatic research has focused on the fish within the Park's lakes (Soto et al. 1994), but the remaining aquatic habitats (e.g., ponds and wetlands) have gone virtually unstudied. In a previous study, we examined wetlands in the Park and provided a classification system based on vegetation, water chemistry, water depth, substrate type, and hydroperiod (Clausen et al. 2006). In contrast, we know very little about the kinds of invertebrates that live in these habitats. We focused most of our aquatic 
Table 1. The number of habitat types sampled during two years in the Torres del Paine National Park, Chile.

\begin{tabular}{lcc}
\hline Habitat type & Year 1 & Year 2 \\
\hline Temporary wetlands & 16 & 31 \\
Semi-permanent wetlands & 25 & 27 \\
Permanent wetlands & 10 & 11 \\
Ponds & 3 & 6 \\
Lakes & 3 & 6 \\
\hline Total & 57 & 81 \\
\hline
\end{tabular}

surveys in the sectors of Laguna Amarga, Lago Toro, and Lago Grey (Fig. 1).

Taxa collection-To determine how aquatic animals were distributed among the aquatic habitats, we sampled 57 sites in January 2000 (year 1). In December 2000-January 2001 (year 2), we sampled these same 57 sites plus 24 additional sites for a total of 81 sites (Table 1). We selected habitats that included a full range of hydroperiods, from the most ephemeral wetlands to the largest lakes.

Because hydroperiod was predicted to affect faunal richness (Wellborn et al. 1996; Wiggins et al. 1980), we classified our sites by hydroperiod using five categories: lakes, ponds, permanent wetlands, semi-permanent wetlands, or temporary wetlands. We defined lakes as large, deep-water bodies in which light could not reach the bottom of the basin (Wetzel, 2001); all of the lakes contained fish (Soto et al. 1994). We defined ponds as large, shallow-water bodies lacking emergent macrophytes in the center (Wetzel, 2001); all of the ponds lacked fish. We defined wetlands as habitats containing hydric soils, hydrophytic vegetation, and possessing surface water for at least part of the year; all of the wetlands lacked fish. Based on our wetland classification system (Clausen et al. 2006), we classified each wetland as either temporary, semi-permanent, or permanent. Plants from the genera Juncus, Eleocharis, and Carex are typically associated with temporary hydroperiods, plants from the genera Hippuris, Myriophyllum, and Ranunculus are typically associated with semi-permanent hydroperiods, and plants from the genus Scirpus are typically associated with permanent hydroperiods (Mitsch \& Gosselink, 2000).
The faunal collection was composed of larval anurans and aquatic macroinvertebrates (Table 2). Animals were collected by two to three people using $18 \times 24 \mathrm{~cm}$ dip nets with a $1 \times 2 \mathrm{~mm}$ mesh and we adjusted our sampling effort to the area of each habitat. This mesh size constrained our collection to those organisms larger than 1 $\mathrm{mm}$, thus we knew a priori that many species of zooplankton $(<1 \mathrm{~mm})$ would not be collected. We attempted to sample all microhabitats within each aquatic habitat (e.g., open water, benthic, and littoral), although water $>1.5 \mathrm{~m}$ deep (i.e. the centers of lakes and ponds) could not be sampled. In habitats too large for complete sampling, we sampled multiple transect lines across the habitats. We also quantified the water chemistry of each habitat by measuring the temperature, $\mathrm{pH}$, dissolved oxygen, salinity, and conductivity using a WTW MultiLine P4 instrument (WTW Measurement Systems, Inc., Ft. Meyers, FL). We preserved all collected animals in $70 \%$ ethanol and then sorted the animals into taxonomic groups (primarily taxonomic families). These animals have been archived at the Carnegie Museum of Natural History in the Section of Invertebrate Zoology in Pittsburgh, PA.

\section{Statistical analysis}

To obtain a general overview of which taxa were the most common and which were rare in Patagonian aquatic communities, we examined the prevalence of the taxa across the landscape. We defined prevalence as the proportion of all habitats that a given taxon inhabited.

Next, we examined patterns in abiotic effects across the hydroperiod gradient. We conducted multivariate analyses of variance to determine how $\mathrm{pH}$, temperature, conductivity (log transformed), salinity (log transformed), and dissolved oxygen varied across the hydroperiod gradient. For significant multivariate effects, we conducted univariate tests. For significant univariate effects, we compared means using Fisher's test.

We then examined patterns of species richness across the hydroperiod gradient. We used presence/absence data from each habitat to calculate the total number of taxa within each 
Table 2. Fauna collected during two years of sampling aquatic habitats in the Torres del Paine National Park.

\begin{tabular}{|c|c|c|c|c|}
\hline Common name & Class & Order & Family & Species (if known) \\
\hline Water mite & Arachnoidea & Acari & & \\
\hline Scud, sideswimmer & Crustacea & Amphipoda & & \\
\hline Water flea & Crustacea & Cladocera & Daphnidae & Daphnia spp. \\
\hline Copepod & Crustacea & Eucopepoda & & \\
\hline Leech & Hirudinea & & & \\
\hline Predaceous diving beetle & Insecta & Coleoptera & Dytiscidae & \\
\hline Unknown beetle & Insecta & Coleoptera & & \\
\hline Water scavenger beetle & Insecta & Coleoptera & Hydrophilidae & \\
\hline Midge larvae & Insecta & Diptera & Chironomidae & \\
\hline Mosquito larvae & Insecta & Diptera & & \\
\hline Mayfly larvae & Insecta & Ephemeroptera & & \\
\hline Water boatman & Insecta & Hemiptera & Corixidae & \\
\hline Dragonfly larvae & Insecta & Odonata & Aeshnidae & \\
\hline Caddisfly larvae & Insecta & Trichoptera & & \\
\hline Tadpole & Lissamphibia & Anura & Leptodactylidae & Pleurodema bufonina \\
\hline Clam & Mollusca & Bivalvia & & \\
\hline Snail & Mollusca & Gastropoda & & \\
\hline
\end{tabular}

habitat and differences in taxonomic richness among the five habitat categories (lakes, ponds, permanent wetlands, semi-permanent wetlands, and temporary wetlands). For each year, we conducted an analysis of variance (ANOVA). When we found a significant effect, we compared means using Fisher's test.

To help understand the mechanistic causes of differences in taxa richness across the hydroperiod gradient, we examined how particular taxa were distributed across the hydroperiod gradient. We calculated the percent of habitats (within each hydroperiod category) in which a given taxon was found. In this way, one can determine whether declines in richness were caused by a general decline in all taxa or by elimination of specific taxa.

\section{RESULTS}

We found a number of general patterns in the distribution of aquatic taxa (Fig. 2). A total of 19 taxa were collected in the surveys. In both years, amphipods and dytiscid beetles dominated the landscape, occupying $81-95 \%$ of all habitats. The moderately common taxa (occupying $40-69 \%$ of all habitats) were the corixids, cladocerans, mosquitoes, copepods, caddisflies, chironomids, and snails. Eight taxa were less common (occupying $3-33 \%$ of all habitats): hydrophilid beetles, leeches, unknown beetles, tadpoles, mites, aeshnid dragonflies, bivalves, and mayflies. Isopods and larval damselflies were quite rare (occupying $1-2 \%$ of all habitats).

There was a significant multivariate effect of abiotic conditions across the hydroperiod gradient (Wilks' $\mathrm{F}=2.8, \mathrm{P}=0.0007$; Fig. 3). The multivariate effect occurred because there were differences in $\mathrm{pH}\left(\mathrm{F}_{4,75}=1.7, \mathrm{P}=0.028\right)$, conductivity $\left(\mathrm{F}_{4,75}=4.5, \mathrm{P}=0.003\right)$, and salinity $\left(\mathrm{F}_{4,75}=4.0, \mathrm{P}=0.005\right)$ across the hydroperiod gradient (temperature and dissolved oxygen did not differ; univariate tests, $\mathrm{P}>0.1$ ). The range of $\mathrm{pH}$ differences was relatively small across the gradient ( $\mathrm{pH}=7.8-8.6)$, but temporary ponds did have significantly lower $\mathrm{pH}$ values than permanent 


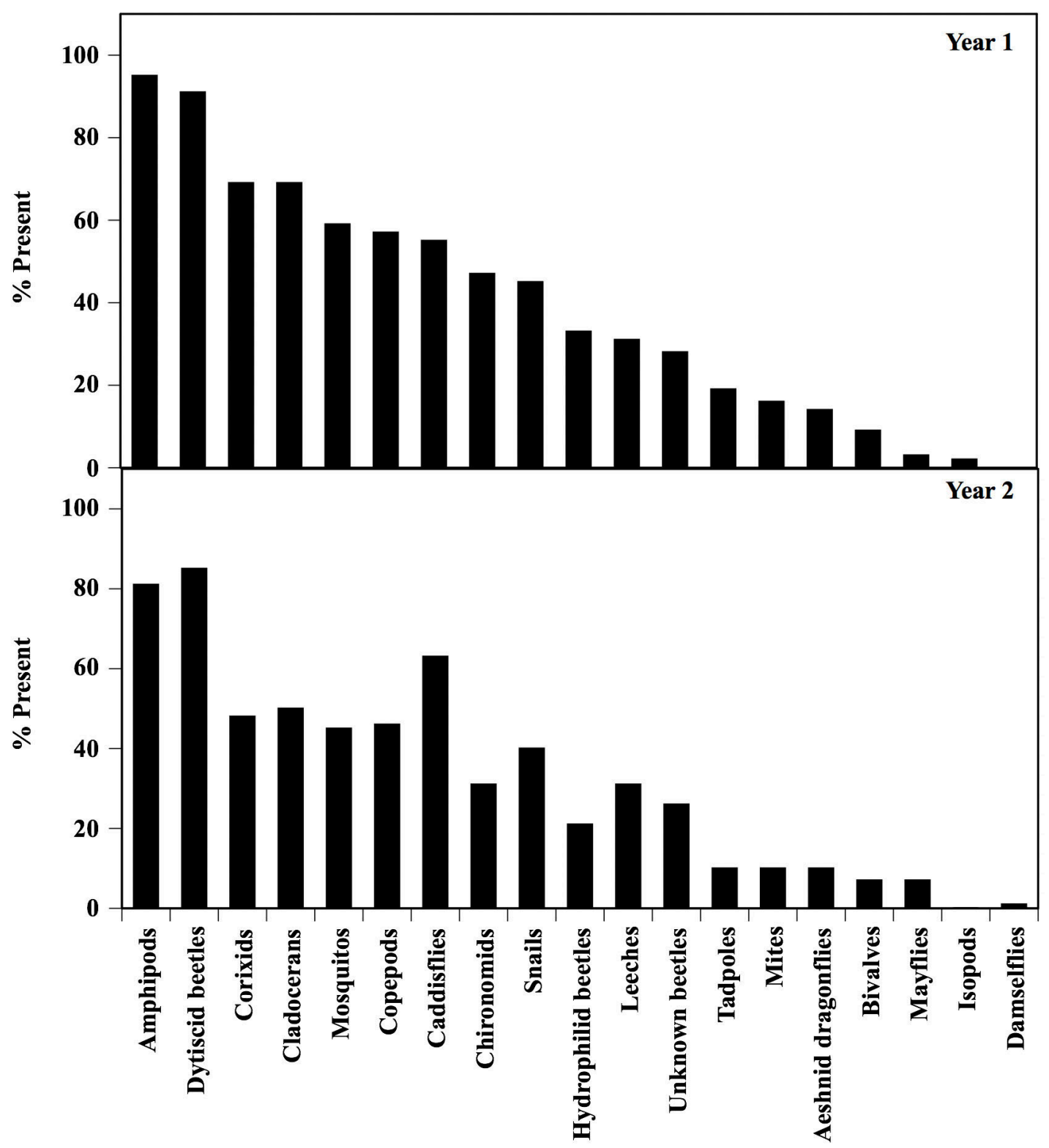

Fig. 2. The percent of habitats occupied by taxa across all habitat types in the Torres del Paine National Park.

wetlands and lakes $(\mathrm{P}<0.03)$. The differences in conductivity and salinity were primarily due to the higher values in ponds than in lakes or wetlands.

We also examined the effect of hydroperiod on taxonomic richness. In year 1 , there was a significant effect of hydroperiod ( $\mathrm{P}$ $=0.040$; Fig. 4). Ponds and the three types of wetlands all contained similar numbers of taxa ( $P>0.05)$, but all three wetland types contained more taxa than lakes $(P \geq 0.01)$. In year 2 , there also was a significant effect of hydroperiod $(P<0.0002)$. Semi-permanent and permanent wetlands contained more taxa than temporary wetlands $(P<0.02)$ and more taxa than lakes $(P$ $<0.006)$. Pond richness did not differ from the other habitat types.

Examining the prevalence of specific taxa within each wetland type illuminated the causes 


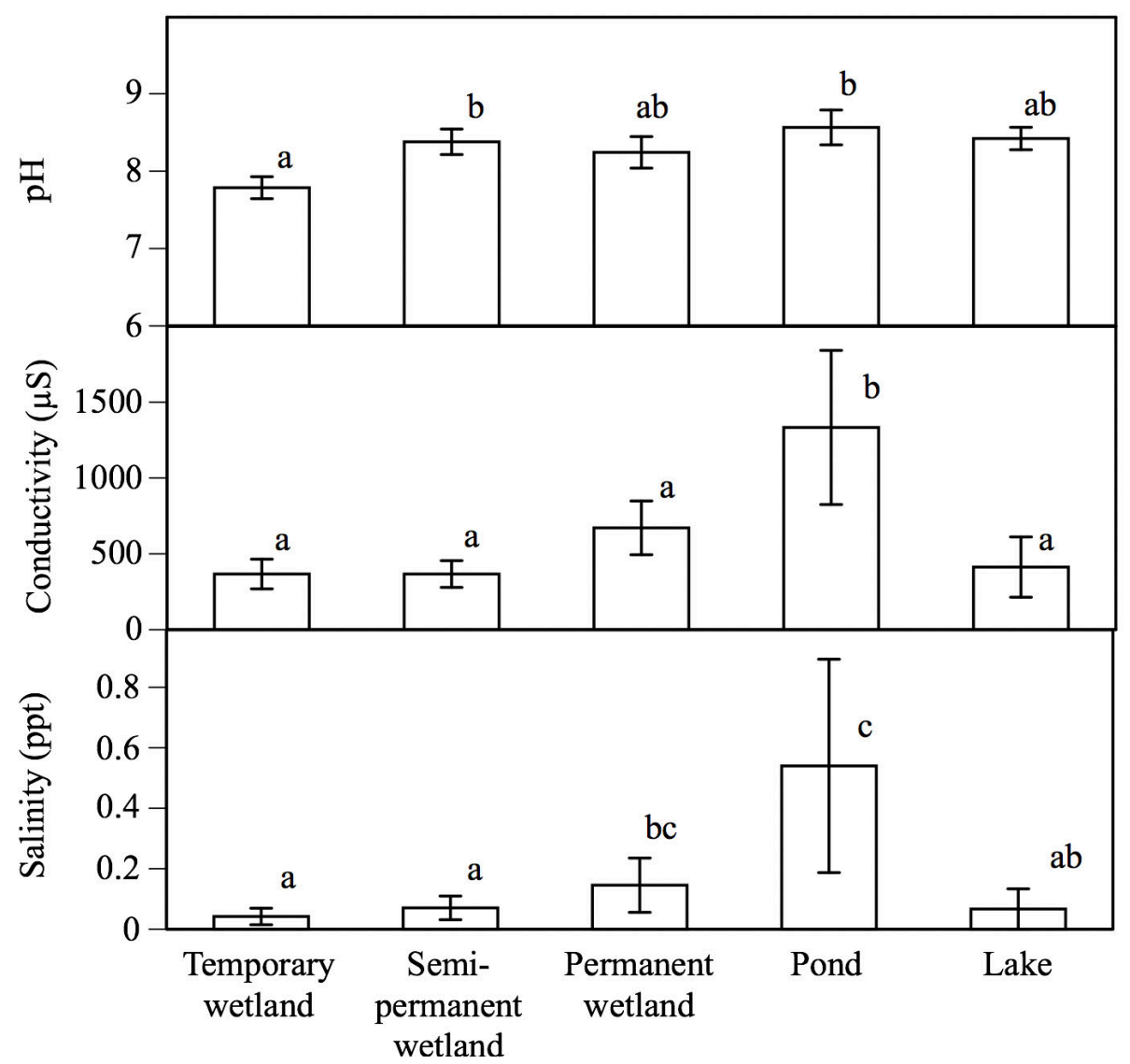

Fig. 3. The changes in abiotic conditions along the hydroperiod gradient in the Torres del Paine National Park. Different letters indicate significantly different means. Data are means $\pm 1 \mathrm{SE}$.

behind the changes in species richness. In year 1 , the three types of wetlands had similar taxonomic composition with similar frequencies (Fig. 5). As a result, the three types of wetlands had similar taxonomic richness. In contrast, ponds were completely lacking caddisflies, snails, hydrophilid beetles, tadpoles, water mites, and aeshnid dragonflies. Lakes were completely lacking cladocerans, larval mosquitoes, copepods, snails, hydrophilid beetles, the unknown beetles, tadpoles, water mites, and aeshnid dragonflies. However, lakes were the only habitat to contain mayflies. As a result, ponds and lakes exhibited increasingly lower taxonomic richness than the wetlands.

In year 2, we again observed similar taxonomic compositions within each of the three wetland types (Fig. 6). However, in this year of higher sample sizes, all taxa were less prevalent in the temporary wetlands compared to the semi-permanent and permanent wetlands. As a result, temporary wetlands contained lower mean taxonomic richness. Ponds completely lacked caddisflies, hydrophilid beetles, tadpoles, water mites, and bivalves. While lakes were the only habitat to contain mayflies, lakes completely lacked cladocerans, mosquito larvae, copepods, hydrophilid beetles, tadpoles, water mites, and aeshnid dragonflies. As a result, ponds and lakes exhibited increasingly lower taxonomic richness than the semi-permanent and permanent wetlands over the two sampling years.

\section{DISCUSSION}

The results of this study suggest that hydroperiod plays a major role in organizing the aquatic communities of the Patagonia. In the first 


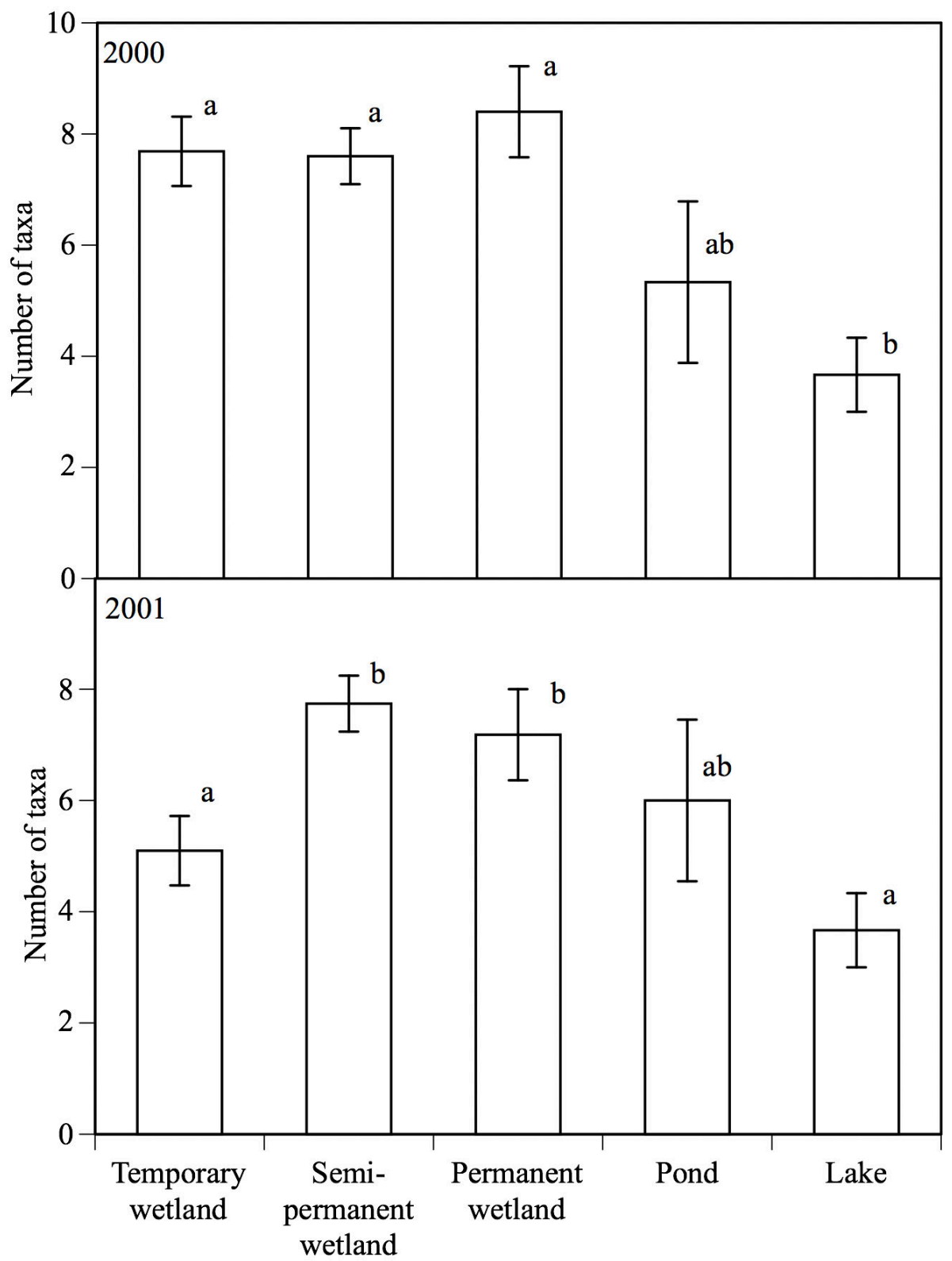

Fig. 4. The number of taxa found along a hydroperiod gradient in the Torres del Paine National Park during year 1 (upper panel) and year 2 (lower panel). Different letters indicate significantly different means (year $1, \mathrm{P}=0.048$; year $2, \mathrm{P}<0.001$ ). Data are means $\pm 1 \mathrm{SE}$.

year, we found that taxonomic richness was highest in wetlands and progressively lower in ponds and lakes. In the second year (with larger sample sizes), we found that richness was actually lower in temporary wetlands, high in more permanent wetlands, and then low again as we moved to ponds and lakes. This supports the relationship found throughout North America (Wiggins et al. 1980, Wellborn et al. 1996).

The mechanisms underlying these decreases in richness differed on each end of the hydroperiod gradient. As we moved from permanent wetlands to temporary wetlands, there was a similar composition of taxa. However, the frequency at 


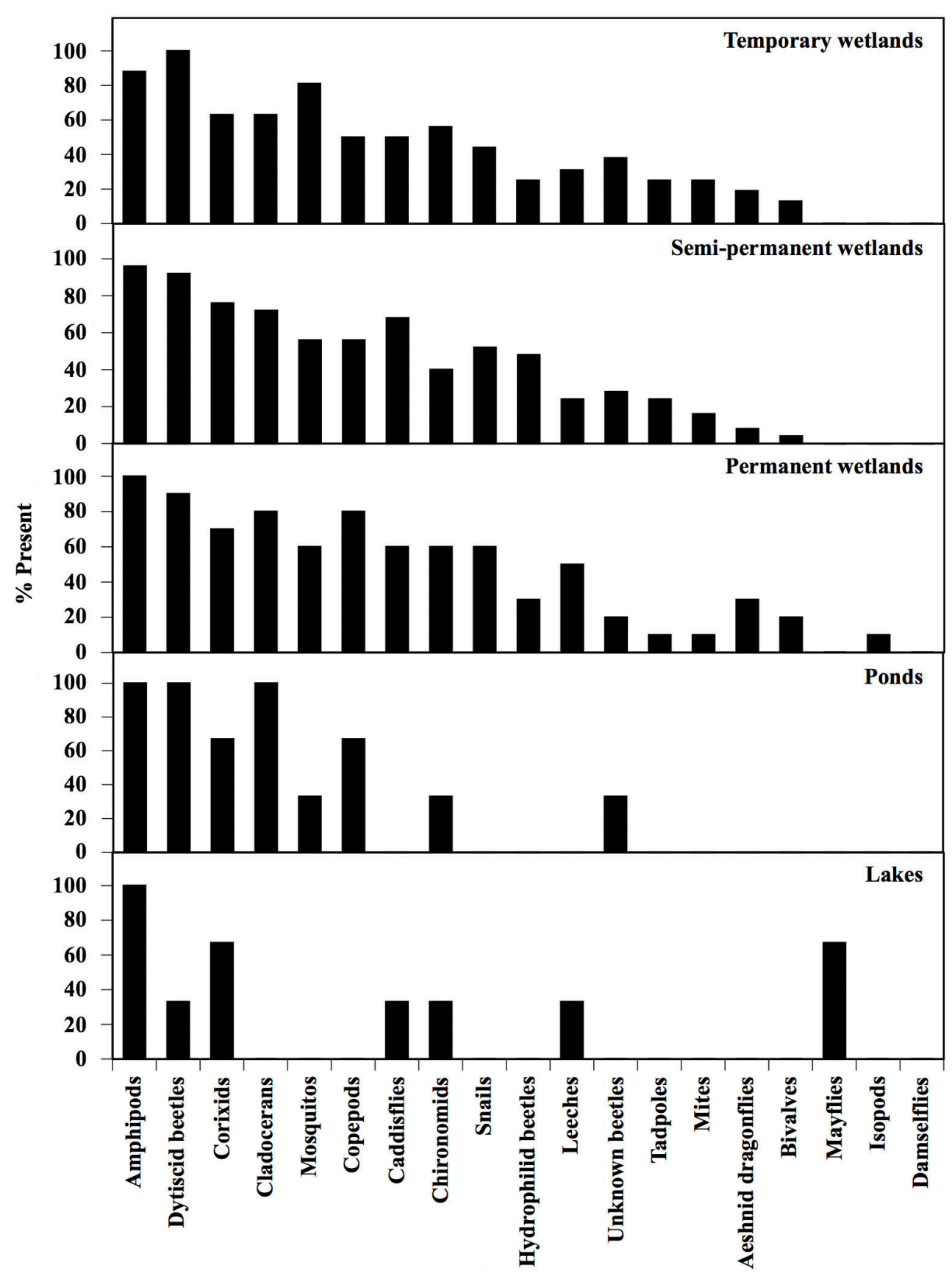

Fig. 5. The percent of habitats occupied by taxa within a given hydroperiod category in the Torres del Paine National Park. Data are from year 1.

which all members of this composition occupied temporary wetlands was relatively low, causing a general decline in mean taxonomic richness. Thus, while a large number of taxa can live in temporary wetlands, few possess the adaptations necessary to live in habitats with very short hydroperiods (e.g., rapid development or resting eggs; Wiggins et al. 1980; Jeffries, 1994). In fact, among the temporary wetlands in our study, those with extremely short hydroperiods contained only caddisflies. 


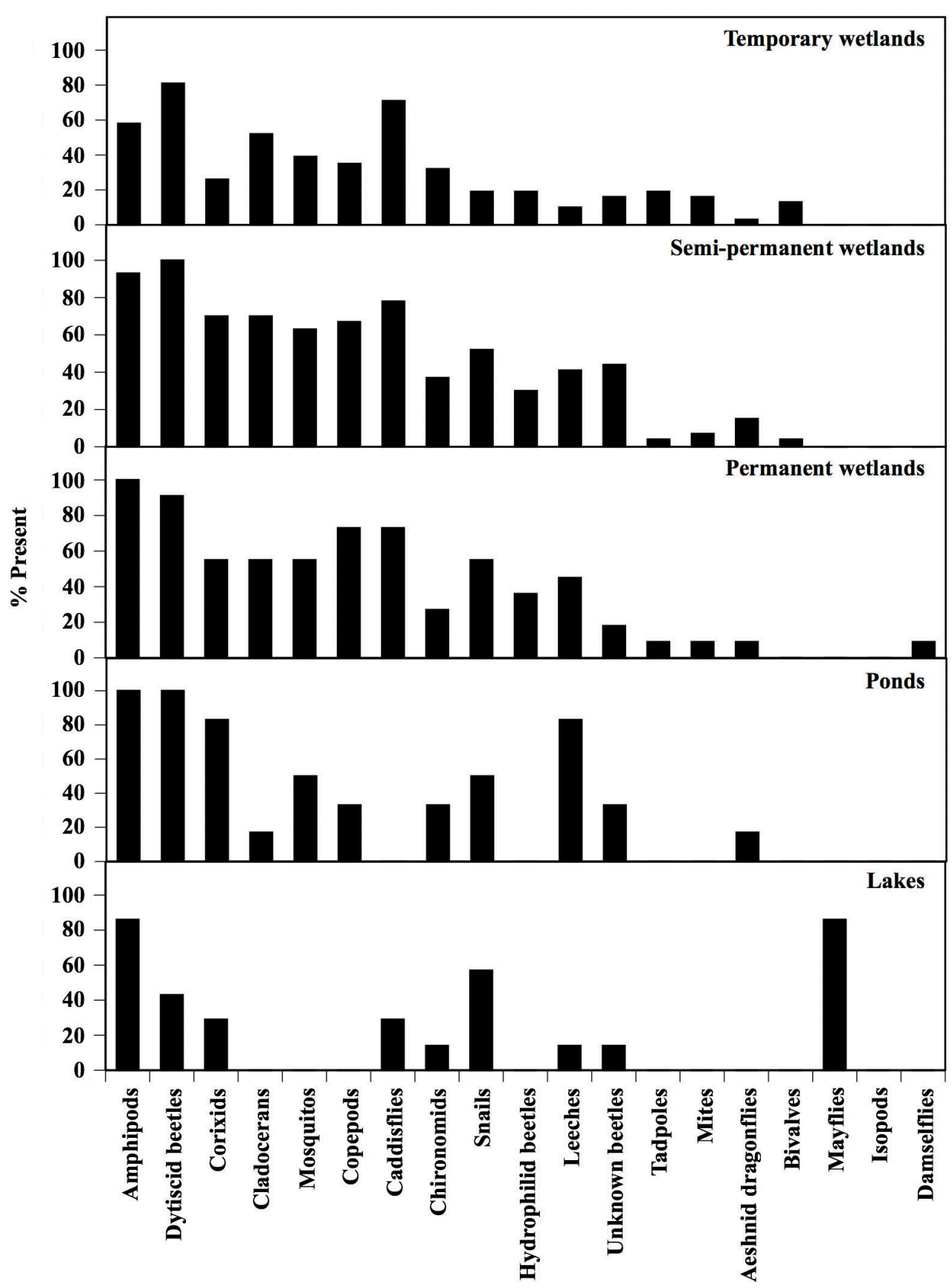

Fig. 6. The percent of habitats occupied by taxa within a given hydroperiod category in the Torres del Paine National Park. Data are from year 2.

As we moved from the permanent wetlands to the lakes, we observed that many taxa were completely absent. In other words, lakes were a highly effective filter that prevented successful colonization by many invertebrates. Fish presence in lakes was the most likely cause of this filter because fish are voracious predators that can completely exclude many species of vertebrates and invertebrates (Brooks \& Dodson, 1965; Dale et al. 1985; Werner \& McPeek, 1994). Fish are 
not found in the temporary and semi-permanent wetlands due to repeatedly dry conditions. Also, fish are typically not found in permanent wetlands and ponds due to either a lack of colonization ability or to periodic anoxic conditions (Tonn \& Magnuson, 1982; Rahel, 1984).

Because fish live in the lakes, the coexisting invertebrate species must be well adapted to avoid fish predation. For example, corixids are not a primary food choice of fish (Macan, 1965) and this may explain why the corixids coexist with fish. Amphipods and mayflies were found in very high densities with fish, but they were found almost exclusively on the undersides of rocks, a common habitat choice for these species and other species susceptible to predation by fish (Merritt \& Cummins, 1978; Borror et al. 1989; Turner et al. 2000). Further, the amphipods in the lakes are considerably smaller than the amphipods found in the wetlands and ponds (Glaude, 2002) which is likely an evolved response to fish preference for large prey and a life history strategy in which prey allocate resources to early reproduction rather than growth (Brooks \& Dodson, 1965; Hall et al. 1970; Wellborn, 1994). The evolution of smaller body sizes is also likely the reason that we collected cladocerans and copepods in the wetlands but not in the lakes. Cladocerans and copepods have both been documented in the lakes (Soto et al. 1994), but they are apparently too small to be collected by our $1 \mathrm{~mm}$ mesh dipnets. Because numerous small species of small zooplankton can exist across the hydroperiod gradient, we were not able to assess how these taxa might alter the richness patterns that we observed.

In more general terms, the drying of the habitats associated with shorter hydroperiods functions as a type of disturbance (Wellborn et al. 1996; Skelly et al. 1999; Mitsch \& Gosselink, 2000). Previous investigations suggest that species richness typically is lowest when disturbance is either common or rare, while species richness is highest when disturbance is intermediate in frequency (Connell, 1975; Sousa, 1979). For example, intermediate disturbance from wave action or predation causes higher algal diversity in marine habitats (Connell, 1975; Lubchenco, 1978; Sousa, 1979; Levin \& Paine, 1974) and higher insect diversity in riverine wetlands
(Whiles \& Goldowitz, 2001). In this study, we found that taxonomic richness was highest with intermediate hydroperiods, suggesting that our aquatic communities lend further support to the intermediate disturbance hypothesis.

While hydroperiod and fish predation can have major impacts on the richness of aquatic communities, the abiotic effects of water chemistry can also play a role (Pennak, 1989; Dunson \& Travis, 1991; Wetzel, 2001). In this study, we found differences in $\mathrm{pH}$, conductivity, and salinity among some of the habitats. However, the differences were either small or within tolerance limits for aquatic organisms (Wiederholm, 1984; Ward, 1992; Wetzel, 2001). Further, the patterns of change in water chemistry did not match the changes that we observed in taxonomic richness. Therefore, it is unlikely that water chemistry played an important role in the distribution of taxa.

In aquatic communities, the distribution of species is often quite broad across the hydroperiod gradient at the family and genus levels, but is typically narrow and finely divided at the species level (Wellborn et al. 1996). For example, Rana tadpoles occur in all types of aquatic habitats in the midwestern United States, but $R$. sylvatica occupies most temporary wetlands, $R$. pipiens and $R$. clamitans occupy semi-permanent wetlands, and $R$. catesbeiana occupies lakes containing fish (Collins \& Wilbur, 1979; Dale et al. 1985). In the current study, we were unable to identify most of the taxa to the level of species, making it possible that many of our taxa consisted of multiple species. However, the initial work on our archived samples by the Carnegie Museum of Natural History suggests that our taxonomic groupings are, in fact, composed of single species (J. Rawlins, Curator of Invertebrates, personal communication). Thus, the reported changes in taxonomic richness are likely changes in species richness. Further, unlike the patterns observed in North American systems, a number of taxa in Patagonian wetlands appear to be widespread generalists across the entire gradient (amphipods, dytiscid beetles, corixids, chironomids, snails, and leeches). Most of the remaining taxa were specialized to wetlands and ponds, although one taxa (mayflies) appears specialized to live in lakes.

This relatively large proportion of habitat 
generalists coincides with a relatively low diversity of species. In similar surveys of aquatic habitats that we have conducted in southeastern Michigan $\left(42^{\circ} \mathrm{N}\right.$ latitude), we find a much higher diversity of species (including 31 species of dytiscid beetles, 33 species of larval dragonflies, and 16 species of snails) and many of these species only live along one part of the hydroperiod (Werner et al. 2007; McCauley et al. 2008; Hoverman et al. 2011). The lower species diversity and wider ranges along the hydroperiod in Patagonian communities suggests that there has been little or no selection pressure favoring the evolution of habitat specialists within genera or families (Rosenzweig, 1995).

Conclusions-This appears to be one of the few studies to examine the distribution of aquatic organisms in the Patagonian region of South America and is a critical first step in understanding the aquatic ecology of the region. The patterns and processes that govern aquatic biodiversity in the Patagonia appear to be the same patterns and processes that govern biodiversity in North America. Thus, while lakes are the largest and most obvious aquatic habitats, they are not the source of most of the aquatic biodiversity. Therefore, it is critical that we protect all habitats across the hydroperiod gradient.

The present study is an important first step, but a great deal of future work is necessary to understand the ecology of the aquatic habitats of the Patagonia. First, one would like to identify the taxa to species to determine how many species live in the region and whether we have any previously undescribed species. Second, it would be beneficial to extend these surveys over several years and throughout the spring and summer months to determine how species distributions (and their relative abundances) fluctuate over time. Third, with this understanding of how the taxa are distributed, it could be insightful to isolate the causative agents of these distributions and understand the mechanistic underpinnings of the food web dynamics. This three-pronged approach will allow us to better understand the ecology of Patagonian aquatic communities and ensure their preservation.

\section{ACKNOWLEDGEMENTS}

We thank the Chilean Forest and Park
Service (CONAF) for logistical support in the Torres del Paine National Park. Jason Hoverman, Oscar Guineo, Gladys Garay, and numerous expedition participants aided in the field work. John Clausen, Jason Hoverman, Robert Neumann, April Randle, and Nancy Schoeppner provided comments on the manuscript. This research was supported by the University of Connecticut Patagonia Research Project and an NSF grant to RAR (DEB 99-03761).

\section{LITERATURE CITED}

Borror, D. J., Triplehorn, C. A., \& Johnson, N.F. (1989). An Introduction to the Study of Insects, $6^{\text {th }}$ ed. Saunders College Publishing. Philadelphia, PA.

Brooks, J. L., \& Dodson, S. I. (1965). Predation, body size, and composition of plankton. Science, 150, 28-35.

Burroni, N. E., Marinone, M. C., Freire, M. G., Schweigmann, N., \& Loetti, M. V. (2011). Invertebrate communities from different wetland types of Tierra del Fuego. Insect Conservation and Diversity, 4, 39-45.

Clausen, J. C., Ortega, I. M, Glaude, C. M., Relyea, R. A., Garay, G., \& Guineo, O. (2006). Classification of wetlands in a Patagonian National Park, Chile. Wetlands, 26, 217229.

Collins, J. P., \& Wilbur, H. M. (1979). Breeding habits and habitats of amphibians of the Edwin S. George Reserve, Michigan, with notes on the local distribution of fishes. Occasional Papers, Museum of Zoology, Univ. of Michigan, 686, 1-34.

Connell, J. H. (1975). Some mechanisms producing structure in natural communities: a model and evidence from field experiments, p. 460490. In M. L. Cody, \& J. M. Diamond (Eds.), Ecology and Evolution of Communities. Belknap Press.

Connell, J. H. (1983). On the prevalence and relative importance of interspecific competition: evidence from field experiments. American Naturalist, 122, 661-696.

Dale, J. M., Freeman, B., \& Kerekes, J. (1985). Acidity and associated water chemistry of amphibian habitats in Nova Scotia. Canadian Journal of Zoology, 63, 97-105. 
Dunson, W. A., \& Travis, J. (1991). The role of abiotic factors in community organization. American Naturalist, 138, 1067-1091.

Epele, L. B., \& Miserendino, M. L. (2015). Environmental Quality and Aquatic Invertebrate Metrics Relationships at Patagonian Wetlands Subjected to Livestock Grazing Pressures. PLoS ONE, 10(10), e0137873.

Epele L. B., \& Miserendino, M. L. (2016). Temporal dynamics of invertebrate and aquatic plant communities at three intermittent ponds in livestock grazed Patagonian wetlands. Journal of Natural History, 50, 11-12,

Glaude, C. M. (2002). Aquatic fauna in three regions of Torres del Paine National Park, Chile. M.S. thesis, University of Connecticut.

Hall, D. J., Cooper, W. E., \& Werner, E. E. (1970). An experimental approach to the production dynamics and structure of freshwater animal communities. Limnology Oceanography, 15, 839-928.

Hoverman, J. T., Davis, C. J., Werner,E. E, Skelly, D. K., Relyea, R. A., \& Yurewicz, K. L. (2011). Environmental gradients and the structure of freshwater snail communities. Ecography, 34, 1039-1048.

Jeffries, M. (1994). Invertebrate communities and turnover in wetland ponds affected by drought. Freshwater Biology, 32, 603-612.

Leibold, M. A. (1989). Resource edibility and the effects of predators and productivity on the outcome of trophic interactions. American Naturalist, 134, 922-949.

Levin, S. A., \& Paine, R. T. (1974). Disturbance, patch formation and community structure. Proceeding National Academy of Sciences of the United States of America, 71, 2744-47.

Lubchenco, J. (1978). Plant species diversity in a marine intertidal community: importance of herbivore food preference and algal competitive abilities. American Naturalist, 112, 23-39.

Macan, T. T. (1965). Predation as a factor in the ecology of water bugs. Journal of Animal Ecology, 34, 691-698.

Marchant, R., Hrist, A., Norris, R. H., Butcher,R., Metzeling, L., \& Tiller, D.
(1997). Classification and prediction of macroinvertebrate assemblages from running waters in Victoria, Australia. Journal of the North American Benthological Society, 16, 664-681.

McCauley, S. J., Davis, C. J., Relyea, R. A., Yurewicz, K. L, Skelly, D. K., \& Werner, E. E. (2008). Metacommunity patterns in larval odonates. Oecologia, 158, 329-342.

Menge, B. A. (1995). Indirect effects in marine rocky intertidal interaction webs: patterns and importance. Ecological Monographs, $65,21-74$

Merritt, R. W., \& Cummins, K. W. (1978). An Introduction to the Aquatic Insects of North America. Dubuque, Iowa: Kendall/Hunt Publishing Co.

Mitsch, W. J., \& Gosselink, J. G. (2000). Wetlands. $3^{\text {rd }}$ ed. Wiley. New York: Chichester,

Pennak, R. W. (1989). Freshwater Invertebrates of the United States: Protozoa to Mollusca. $3^{\text {rd }}$ ed., Wiley. New York.

Rahel, F. J. (1984). Factors structuring fish assemblages along a bog successional gradient. Ecology, 65, 1276-1289.

Reynoldson, T. B., Norris, R. H., Resh, V. H., Day, K. E., \& Rosenberg, D. M. (1997). The reference condition: a comparison of multimetric and multivariate approaches to assess water-quality impairment using benthic macroinvertebrates. Journal of the North American Benthological Society, $16,833-852$.

Rosenzweig, M. (1995). Species Diversity in Space and Time. Cambridge University Press.

Schneider, D. W., \& Frost, T. M. (1996). Habitat duration and community structure in temporary ponds. Journal of the North American Benthological Society, 15, 6486.

Schoener, T. W. (1983). Field experiments on interspecific competition. American Naturalist, 122, 240-285.

Skelly, D. K., Werner, E. E., \& Cortwright, S. A. (1999). Long-term distributional dynamics of a Michigan amphibian assemblage. Ecology, 80, 2326-2337.

Snodgrass, J. W., Lawrence Bryan, Jr., A., \& Burger, J. (2000). Development of 
expectations of larval amphibian assemblage structure in Southeastern depression wetlands. Ecological Applications, 10, 1219-1229.

Soto, D., Campos, H., Steffen, W., Parra, O., \& Zuniga, L. (1994). The Torres del Paine lake district (Chilean Patagonia): A case of potentially N-limited lakes and ponds. Archiv für Hydrobiologie/Supplement, 99, 181-197.

Sousa, W. P. (1979). Experimental investigations of disturbance and ecological succession in a rocky intertidal algal community. Ecological Monograph, 49, 227-54.

Tonn, W. M., \& Magnuson, J. J. (1982). Patterns in the species composition and richness in fish assemblages in northern Wisconsin lakes. Ecology, 63, 1149-1166.

Turner, A. M., Bernot, R. J., \& Boes, C. M. (2000). Chemical cues modify species interactions: The ecological consequences of predator avoidance by freshwater snails. Oikos, 88, 148-158.

Ward, J. V. (1992). Aquatic Insect Ecology. New York: John Wiley \& Sons, Inc.

Wellborn, G. A. (1994). Size-biased predation and prey life histories: A comparative study of freshwater amphipod populations. Ecology, 75, 2104-2117.

Wellborn, G. A., Skelly, D. K., \& Werner, E. E. (1996). Mechanisms creating community structure across a freshwater habitat gradient. Annual Review of Ecology and Systematics, 27, 337-363.
Werner, E. E., \& McPeek, M. A. (1994). Direct and indirect effects of predators on two anuran species along an environmental gradient. Ecology, 75, 1368-1382.

Werner, E. E., Skelly, D. K., Relyea, R. A., \& Yurewicz, K. L. (2007). Amphibian species richness across environmental gradients. Oikos, 116, 1697-1712.

Wetzel, R. G. (2001). Limnology: Lake and River Ecosystems, $3^{\text {rd }}$ ed. Academic Press.

Whiles, M. R., \& Goldowitz, B. S. (2001). Hydrologic influences on insect emergence production from Central Platte River wetlands. Ecological Applications, 11, 1829-1842.

Wiederholm, T. (1984). Responses of aquatic insects to environmental pollution, p. 508557. En V. H. Resh \& D. M. Rosenberg (Eds.), The Ecology of Aquatic Insects (625 pp.) New York: Praeger Publishers.

Wiggins, G. B., Mackay, R. J., \& Smith, I. M. (1980). Evolutionary and ecological strategies of animals in annual temporary pools. Archiv für Hydrobiologie/Supplement, 58, 97206.

Wollheim, W. M., \& Lovvorn, J. R. (1996)(. Effects of macrophyte growth forms on invertebrate communities in saline lakes of the Wyoming High Plains. Hydrobiologia, 323, 83-96.

Wright, J. F. (1995). Development and use of a system for predicting the macroinvertebrate fauna in flowing waters. Austral Ecology, 20, 181-197. 